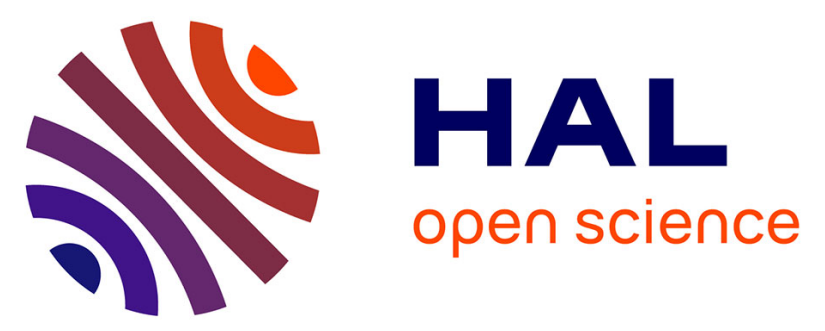

\title{
Identification of Priority Areas for the Conservation of Stream Fish Assemblages: Implications for River Management in France
}

Anthony Maire, Pascal Laffaille, Jean-François Maire, Laëtitia Buisson

\section{To cite this version:}

Anthony Maire, Pascal Laffaille, Jean-François Maire, Laëtitia Buisson. Identification of Priority Areas for the Conservation of Stream Fish Assemblages: Implications for River Management in France. River Research and Applications, 2016, 33 (4), pp.524-537. 10.1002/rra.3107 . hal-01426354

\section{HAL Id: hal-01426354 https://hal.science/hal-01426354}

Submitted on 2 Jul 2021

HAL is a multi-disciplinary open access archive for the deposit and dissemination of scientific research documents, whether they are published or not. The documents may come from teaching and research institutions in France or abroad, or from public or private research centers.
L'archive ouverte pluridisciplinaire HAL, est destinée au dépôt et à la diffusion de documents scientifiques de niveau recherche, publiés ou non, émanant des établissements d'enseignement et de recherche français ou étrangers, des laboratoires publics ou privés. 


\title{
IDENTIFICATION OF PRIORITY AREAS FOR THE CONSERVATION OF STREAM FISH ASSEMBLAGES: IMPLICATIONS FOR RIVER MANAGEMENT IN FRANCE
}

\author{
A. MAIRE ${ }^{\mathrm{a} *, \dagger}$, P. LAFFAILLE ${ }^{\mathrm{b}, \mathrm{c}}$, J.-F. MAIRE ${ }^{\mathrm{d}}$ AND L. BUISSON $^{\mathrm{b}, \mathrm{e}}$ \\ a Irstea; UR HYAX, Pôle Onema-Irstea Hydroécologie des plans d'eau; Centre d'Aix-en-Provence, Aix-en-Provence, France \\ b CNRS; UMR 5245 EcoLab, (Laboratoire Ecologie Fonctionnelle et Environnement), Toulouse, France \\ ${ }^{\mathrm{c}}$ Université de Toulouse, INP, UPS; EcoLab; ENSAT, Castanet Tolosan, France \\ d ONERA, The French Aerospace Lab Composites Department, Châtillon, France \\ ${ }^{\mathrm{e}}$ Université de Toulouse, INP, UPS; EcoLab, Toulouse, France
}

\begin{abstract}
Financial and human resources allocated to biodiversity conservation are often limited, making it impossible to protect all natural places, and priority areas for protection must be identified. In this study, we applied ecological niche models to predict fish assemblages in the stream network of France. Four non-correlated conservation objectives were derived from these species assemblages: taxonomic diversity, functional diversity, natural heritage importance and socio-economic value. We proposed a multi-objective prioritization method based on the Pareto optimality principle to rank the planning units (i.e. 6097 subcatchments) according to their inherent trade-offs between the four conservation objectives. Four types of hydrosystems of great conservation importance presenting specific fish assemblages were identified: (i) the most upstream areas of large catchments; (ii) the most downstream areas of large catchments; (iii) the small coastal catchments of the English Channel and the Atlantic Ocean; and (iv) the Mediterranean streams of medium altitude. The fish assemblages characterizing these hydrosystems were complementary and representative of the entire fish fauna of France. Most of these priority subcatchments were found to be practically suitable for the implementation of conservation actions, which is very promising for the protection of river biodiversity.
\end{abstract}

KEY WORDS: biodiversity; conservation planning; decision-making; species distribution models; Pareto optimality; prioritization

\section{INTRODUCTION}

Given the increasing loss of freshwater biodiversity worldwide, immediate conservation actions are crucially required to protect aquatic ecosystems (Dudgeon et al., 2006; Vörösmarty et al., 2010). However, it is impossible to protect all natural areas because the financial and human resources available for conservation are limited (Wilson et al., 2006). Consequently, there is an urgent need to identify freshwater environments that should be protected as a priority (Abell et al., 2007; Strayer and Dudgeon, 2010). Most conservation planning studies have evaluated the conservation priority of an area based on its species composition (i.e. species-based approach) (Myers et al., 2000; Darwall and Vié, 2005). Species can be targeted directly by identifying a reserve network that ensures the protection of the whole regional species pool (Collier, 2011). Species surrogates such as diversity metrics can also be used to prioritize

\footnotetext{
*Correspondence to: A. Maire, Irstea, UR HYAX, Pôle Onema-Irstea Hydroécologie des plans d'eau, Centre d'Aix-en-Provence, Aix-en-Provence, France.

E-mail: anthony.maire@edf.fr

${ }^{\dagger}$ Present address: EDF R\&D; LNHE, (Laboratoire National d'Hydraulique et Environnement), Chatou, France
}

areas for conservation (e.g. Bergerot et al., 2008; Strecker et al., 2011). These diversity metrics can be used to build various conservation objectives (e.g. species richness, species conservation status, functional diversity), which can result in a comprehensive prioritization when the conservation objectives are considered together and are not redundant (Maire et al., 2013). However, counterproductive decision-making issues are likely to occur if these objectives are found conflicting (Rothley, 1999; Ascough et al., 2008). For instance, the quantification of the conservation interest of an assemblage made up of numerous but exotic species or presenting only few but rare species represents a complex challenge. Conservation planners should thus develop multi-objective prioritization methods in order to reach a satisfying compromise between contradictory conservation objectives (Arthur et al., 2004; Kramer et al., 2013).

Freshwater fish constitute one of the most severely threatened taxonomic groups (Collares-Pereira and Cowx, 2004; Darwall and Vié, 2005) because of high sensitivity to the various and increasing alterations affecting aquatic habitats (Dudgeon et al., 2006). They are therefore of great conservation concern, but the environmental features of the freshwater ecosystems the most appropriate for the protection of fish biodiversity have been little investigated. Yet, 
many studies have examined the spatial patterns of fish diversity at the scale of the stream network (e.g. Céréghino et al., 2005; Pont et al., 2005; Lasne et al., 2007; Buisson and Grenouillet, 2009; Kanno et al., 2012), but only few of them have linked their findings to conservation planning issues. Although the need of designing protected areas dedicated to freshwater ecosystems is now well acknowledged (Saunders et al., 2002; Abell et al., 2007; Nel et al., 2009), the definition and implementation of efficient freshwater conservation strategies remain a major challenge for the protection of aquatic biodiversity (Strayer and Dudgeon, 2010; Collier, 2011; Hermoso et al., 2015). The characterization of the environmental and biological features of priority areas for conservation could lead to a comprehensive and locally relevant management of freshwater ecosystems (Roux et al., 2016).

In this study, we defined several conservation objectives based on different aspects of the diversity of fish assemblages (Maire et al., 2013) in French streams. We then proposed a prioritization procedure based on the Pareto optimality principle (Zitzler and Thiele, 1999) which classifies the solutions of a multi-objective optimization problem according to a relationship of dominance between them (Kennedy et al., 2008; Irisarri et al., 2011). Our goals were to identify sets of priority areas for the protection of fish biodiversity in France and to describe them on the basis of their environmental and biological features. Our final aim was to derive key principles to support river biodiversity management in France, which might also be applied elsewhere.

\section{MATERIALS AND METHODS}

\section{Study area and planning units}

The French hydrographic network was divided into 6097 homogeneous subcatchments $\left(89 \mathrm{~km}^{2}\right.$ on average) according to the French national hydraulic database BD CARTHAGE® (IGN; see www.sandre.eaufrance.fr/ Referentiel-hydrographique). These subcatchments were defined as planning units because this spatial resolution proved to be appropriate and ecologically relevant for prioritizing freshwater environments (Linke et al., 2008; Hermoso and Kennard, 2012).

\section{Fish data}

Fish data were provided by the French National Agency for Water and Aquatic Environment (ONEMA). This database gathers more than 20000 stream reaches that were sampled by standardized electrofishing surveys between 1994 and 2011 (see Poulet et al., 2011 for details). Among the 6097 subcatchments (i.e. planning units) considered in this study, $2889(47.4 \%)$ subcatchments were sampled at least once. The sampled subcatchments were evenly distributed over entire France and covered all types of streams, ranging from small headwater torrents to large lowland rivers. Fish species presence-absence data of the different stream reaches or/and sampling occasions included in the same subcatchment were pooled. A total of 81 different fish species were sampled but some of them were omitted from this study because of insufficient detection (e.g. the European seabass Dicentrarchus labrax in estuarine environments) or very unreliable presence (e.g. the fathead minnow Pimephales promelas). A total of 74 fish species was considered in the analyses (Table I).

\section{Environmental predictors}

Eleven environmental variables relevant to explain the spatial distribution of stream fish species (Oberdorff et al., 2001; Pont et al., 2005; Buisson and Grenouillet, 2009) were computed using ArcGIS 10 software (ESRI, 2011) and were used to characterize the 6097 subcatchments. Among these variables, four described the hydrography of the subcatchments: the mean slope (\%o), the area of the drainage catchment upstream of the considered subcatchment $\left(\mathrm{km}^{2}\right)$, the hydro-ecoregion (hereafter 'HER') (Adour basin, English Channel basins, Garonne basin, Loire basin, Mediterranean basins, North Sea basins, Rhône basin, Seine basin, South Atlantic basins; see Oberdorff et al., 2001) and the relative location of the subcatchment along the upstream-downstream gradient which ranged from 0 (the mouth of the catchment) to 1 (the source of the catchment). For the latter variable, a value of 0.5 thus corresponds to a subcatchment located in the middle of the catchment, halfway between the source and the mouth. Four climatic variables were extracted from the WorldClim database (Hijmans et al., 2005; current conditions based on the period 1950-2000): the mean annual air temperature $\left({ }^{\circ} \mathrm{C}\right)$, the range of air temperature between the coldest and the warmest months $\left({ }^{\circ} \mathrm{C}\right)$, the mean annual rainfall $(\mathrm{mm})$ and the range of rainfall between the driest and the wettest months $(\mathrm{mm})$. Given the lack of water temperature data at such a large scale, air temperatures were used as a proxy for water temperatures (Caissie, 2006). The last three variables described anthropogenic pressures: the population density of the subcatchment (number of inhabitants $/ \mathrm{km}^{2}$ ) (IGN GEOFLA®, see: www.professionnels.ign.fr/geofla), the density of hydraulic works (i.e. number of dams or weirs by river kilometre from the ROE database, see: www. eaufrance.fr) and the proportion of the different land-cover types present in the drainage catchment upstream of the considered subcatchment. For the latter variable, we considered the coarsest level of distinction between land-cover types provided by the European land-cover database CORINE (Bossard et al., 2000). We computed a principal component analysis (PCA) on the percentages of agricultural and forest 
Table I. List of the species studied. The biogeographical origin, percentages of occurrence in all the subcatchments and in the priority subcatchments (i.e. Pareto rank $\leq 3$ ), percentages of occurrence in each cluster and significance of the Fisher exact test are also specified. Species are sorted alphabetically by scientific name

\begin{tabular}{|c|c|c|c|c|c|c|c|c|c|}
\hline \multirow[t]{2}{*}{$\begin{array}{l}\text { Scientific } \\
\text { name }\end{array}$} & \multirow[t]{2}{*}{$\begin{array}{l}\text { Common } \\
\text { name }\end{array}$} & \multirow[t]{2}{*}{$\underset{\mathrm{a}}{\text { Origin }}$} & \multirow{2}{*}{$\begin{array}{l}\text { Occurrence in all } \\
\text { subcatchments } \\
(\%)\end{array}$} & \multirow{2}{*}{$\begin{array}{l}\text { Occurrence in priority } \\
\text { subcatchments } \\
(\%)\end{array}$} & \multicolumn{4}{|c|}{$\begin{array}{l}\text { Occurrence in } \\
\text { clusters }(\%)\end{array}$} & \multirow[t]{2}{*}{$\mathrm{F}^{\mathrm{b}}$} \\
\hline & & & & & I & II & III & IV & \\
\hline Abramis brama & Common bream & $\mathrm{N}$ & 34.1 & 13.3 & 100 & 6.3 & 0 & 0 & $* * *$ \\
\hline $\begin{array}{l}\text { Alburnoides } \\
\text { bipunctatus }\end{array}$ & Schneider & $\mathrm{N}$ & 21.7 & 6.0 & 33.0 & 0 & 0 & 10.3 & $* * *$ \\
\hline Alburnus alburnus & Common bleak & $\mathrm{N}$ & 39.7 & 14.1 & 95.0 & 7.6 & 0 & 4.9 & $* * *$ \\
\hline Alosa alosa & Allis shad & $\mathrm{N}$ & 0.2 & 1.0 & 9.0 & 0 & 0 & 0 & $*$ \\
\hline Alosa fallax fallax & Twaite shad & $\mathrm{N}$ & $<0.1$ & 0.2 & 2.0 & 0 & 0 & 0 & ns \\
\hline $\begin{array}{l}\text { Alosa fallax } \\
\text { rhodanensis }\end{array}$ & $\begin{array}{l}\text { Rhodanian } \\
\text { twaite shad }\end{array}$ & END & $<0.1$ & 0.4 & 2.0 & 0 & 0 & 0.5 & $\mathrm{~ns}$ \\
\hline Ambloplites rupestris & Rock bass & $\mathrm{NE}$ & 0.1 & 0.1 & 1.0 & 0 & 0 & 0 & ns \\
\hline Ameiurus melas & Black bullhead & $\mathrm{NE}$ & 26.8 & 10.5 & 74.0 & 7.2 & 0 & 0 & $* * *$ \\
\hline Anguilla anguilla & European eel & $\mathrm{N}$ & 55.3 & 44.8 & 100 & 97.9 & 0.3 & 29.9 & $* * *$ \\
\hline Aspius aspius & Asp & IE & 2.0 & 3.4 & 29.0 & 0 & 0 & 0 & $* * *$ \\
\hline Atherina boyeri & $\begin{array}{l}\text { Big-scale } \\
\text { sand smelt }\end{array}$ & $\mathrm{N}$ & 0.1 & 0.5 & 3.0 & 0.4 & 0 & 0 & ns \\
\hline Barbatula barbatula & Stone loach & $\mathrm{N}$ & 65.9 & 13.7 & 13.0 & 40.9 & 0 & 4.9 & $* * *$ \\
\hline Barbus barbus & Barbel & $\mathrm{N}$ & 36.8 & 16.5 & 64.0 & 13.5 & 1.7 & 22.3 & $* * *$ \\
\hline Barbus meridionalis & Southern barbel & END & 5.3 & 17.1 & 3.0 & 0 & 0.3 & 78.3 & $* * *$ \\
\hline Blicca bjoerkna & Silver bream & $\mathrm{N}$ & 29.8 & 11.1 & 93.0 & 1.3 & 0 & 0 & $* * *$ \\
\hline Carassius sp. & Crucian carp & IE & 32.4 & 13.4 & 99.0 & 0.8 & 0 & 8.2 & $* * *$ \\
\hline Chelon labrosus & $\begin{array}{l}\text { Thick-lipped } \\
\text { grey mullet }\end{array}$ & $\mathrm{N}$ & 3.5 & 13.4 & 63.0 & 15.6 & 0 & 8.7 & $* * *$ \\
\hline Chondrostoma nasus & Nase & $\mathrm{N}$ & 17.9 & 6.4 & 41.0 & 0 & 0 & 7.6 & $* * *$ \\
\hline Cobitis bilineata & Italian loach & $\mathrm{N}$ & $<0.1$ & 0.0 & 0 & 0 & 0 & 0 & abs \\
\hline Cobitis taenia & Spined loach & $\mathrm{N}$ & 8.9 & 2.5 & 17.0 & 2.1 & 0 & 0 & $* * *$ \\
\hline Cottus aturi & Adour sculpin & END & 1.1 & 6.2 & 0 & 8.0 & 10.1 & 0 & $* *$ \\
\hline Cottus gobio & Common bullhead & $\mathrm{N}$ & 10.3 & 20.0 & 7.0 & 0 & 23.5 & 46.2 & $* * *$ \\
\hline Cottus hispaniolensis & Pyrenean sculpin & END & 0.3 & 1.0 & 0 & 0 & 2.3 & 0.5 & ns \\
\hline Cottus perifretum & Celtic bullhead & $\mathrm{N}$ & 38.6 & 14.1 & 17.0 & 43.5 & 0.6 & 0 & $* * *$ \\
\hline Cottus petiti & Lez sculpin & END & $<0.1$ & 0.0 & 0 & 0 & 0 & 0 & abs \\
\hline Cottus rhenanus & Rhine sculpin & $\mathrm{N}$ & 4.4 & 2.8 & 0 & 0 & 7.0 & 0 & $*$ \\
\hline Cyprinus carpio & Common carp & $\mathrm{NE}$ & 32.8 & 12.8 & 89.0 & 3.4 & 0 & 7.6 & $* * *$ \\
\hline Esox lucius & Pike & $\mathrm{N}$ & 40.4 & 11.9 & 86.0 & 7.2 & 0 & 0 & $* * *$ \\
\hline Gambusia holbrooki & Mosquitofish & IE & 6.2 & 12.0 & 38.0 & 19.8 & 0 & 10.3 & $* * *$ \\
\hline Gasterosteus gymnurus & $\begin{array}{l}\text { Three-spined } \\
\text { stickleback }\end{array}$ & $\mathrm{N}$ & 28.4 & 12.7 & 34.0 & 28.3 & 0.9 & 3.3 & $* * *$ \\
\hline Gobio gobio & Gudgeon & $\mathrm{N}$ & 43.6 & 5.0 & 32.0 & 1.7 & 0 & 3.8 & $* * *$ \\
\hline Gobio lozanoi & Iberian gudgeon & $\mathrm{N}$ & 4.8 & 12.1 & 13.0 & 38.4 & 0.3 & 0 & $* * *$ \\
\hline Gobio occitaniae & $\begin{array}{l}\text { Languedoc } \\
\text { gudgeon }\end{array}$ & END & 26.2 & 11.3 & 33.0 & 1.3 & 9.3 & 16.3 & $* * *$ \\
\hline $\begin{array}{l}\text { Gymnocephalus } \\
\text { cernuus }\end{array}$ & Ruffe & $\mathrm{N}$ & 26.3 & 9.2 & 75.0 & 1.7 & 0 & 0.5 & $* * *$ \\
\hline $\begin{array}{l}\text { Hypophthalmichthys } \\
\text { molitrix }\end{array}$ & Silver carp & $\mathrm{NNE}$ & 0.9 & 1.3 & 7.0 & 0.8 & 0 & 1.1 & ns \\
\hline Lampetra fluviatilis & River lamprey & $\mathrm{N}$ & 2.1 & 5.0 & 8.0 & 14.8 & 0 & 0 & $* * *$ \\
\hline Lampetra planeri & Brook lamprey & $\mathrm{N}$ & 39.5 & 29.1 & 9.0 & 78.9 & 15.1 & 2.2 & $* * *$ \\
\hline Lepomis gibbosus & Pumpkinseed & NE & 42.7 & 16.2 & 98.0 & 13.9 & 0 & 4.9 & $* * *$ \\
\hline Leucaspius delineatus & Moderlieschen & $\mathrm{N}$ & 18.6 & 5.7 & 29.0 & 8.0 & 0.3 & 0 & $* * *$ \\
\hline Leuciscus burdigalensis & Beaked dace & END & 29.2 & 10.1 & 64.0 & 8.9 & 0.3 & 0.5 & $* * *$ \\
\hline Leuciscus idus & Orfe & IE & 1.3 & 4.0 & 35.0 & 0 & 0 & 0 & $* * *$ \\
\hline Leuciscus leuciscus & Common dace & $\mathrm{N}$ & 22.9 & 1.5 & 13.0 & 0 & 0 & 0 & $* * *$ \\
\hline Liza ramada & $\begin{array}{l}\text { Thin-lipped } \\
\text { grey mullet }\end{array}$ & $\mathrm{N}$ & 2.7 & 9.6 & 61.0 & 3.8 & 0 & 7.1 & $* * *$ \\
\hline Lota lota & Burbot & $\mathrm{N}$ & 8.2 & 1.5 & 13.0 & 0 & 0 & 0 & $* * *$ \\
\hline
\end{tabular}


Table I. (Continued)

\begin{tabular}{|c|c|c|c|c|c|c|c|c|c|}
\hline \multirow[t]{2}{*}{$\begin{array}{l}\text { Scientific } \\
\text { name }\end{array}$} & \multirow[t]{2}{*}{$\begin{array}{l}\text { Common } \\
\text { name }\end{array}$} & \multirow[t]{2}{*}{$\underset{\mathrm{a}}{\text { Origin }}$} & \multirow{2}{*}{$\begin{array}{l}\text { Occurrence in all } \\
\text { subcatchments } \\
(\%)\end{array}$} & \multirow{2}{*}{$\begin{array}{l}\text { Occurrence in priority } \\
\text { subcatchments } \\
(\%)\end{array}$} & \multicolumn{4}{|c|}{$\begin{array}{l}\text { Occurrence in } \\
\text { clusters }(\%)\end{array}$} & \multirow[t]{2}{*}{$\mathrm{F}^{\mathrm{b}}$} \\
\hline & & & & & I & II & III & IV & \\
\hline Micropterus salmoides & Large-mouth bass & $\mathrm{NE}$ & 11.8 & 10.7 & 70 & 5.9 & 0 & 4.9 & $* *$ \\
\hline Misgurnus fossilis & Weatherfish & $\mathrm{N}$ & 0.2 & 0.1 & 1.0 & 0 & 0 & 0 & ns \\
\hline Mugil cephalus & Flathead mullet & $\mathrm{N}$ & 0.2 & 1.3 & 6.0 & 0.8 & 0 & 1.6 & $\mathrm{~ns}$ \\
\hline Oncorhynchus mykiss & Rainbow trout & NNE & 14.1 & 17.4 & 14.0 & 12.2 & 14.5 & 31.5 & $* * *$ \\
\hline Pachychilon pictum & Albanian minnow & IE & 2.4 & 0.4 & 2.0 & 0 & 0 & 0.5 & $\mathrm{~ns}$ \\
\hline $\begin{array}{l}\text { Parachondrostoma } \\
\text { toxostoma }\end{array}$ & Soiffe & $\mathrm{N}$ & 16.5 & 12.8 & 36.0 & 17.7 & 0.3 & 17.4 & $* * *$ \\
\hline Perca fluviatilis & European perch & $\mathrm{N}$ & 47.9 & 10.2 & 83.0 & 2.1 & 0 & 0 & $* * *$ \\
\hline Petromyzon marinus & Sea lamprey & $\mathrm{N}$ & 9.6 & 18.2 & 54.0 & 43.9 & 0 & 0 & $* * *$ \\
\hline Phoxinus bigerri & Adour minnow & END & 5.7 & 17.1 & 13.0 & 43.0 & 9.6 & 0 & $* * *$ \\
\hline Phoxinus phoxinus & Eurasian minnow & $\mathrm{N}$ & 55.4 & 10.5 & 0 & 13.1 & 4.9 & 23.4 & $* * *$ \\
\hline Phoxinus septimaniae & Languedoc minnow & END & 3.0 & 8.6 & 10 & 0.8 & 1.7 & 30.4 & $* * *$ \\
\hline Platichthys flesus & Flounder & $\mathrm{N}$ & 6.1 & 15.0 & 58.0 & 29.5 & 0.3 & 0.5 & $* * *$ \\
\hline $\begin{array}{l}\text { Proterorhinus } \\
\text { semilunaris }\end{array}$ & $\begin{array}{l}\text { Western } \\
\text { tubenose goby }\end{array}$ & IE & $<0.1$ & 0.2 & 2.0 & 0 & 0 & 0 & ns \\
\hline Pseudorasbora parva & Stone moroko & IE & 16.0 & 9.2 & 75.0 & 0.8 & 0 & 1.6 & $* * *$ \\
\hline Pungitius laevis & $\begin{array}{l}\text { Nine-spined } \\
\text { stickleback }\end{array}$ & $\mathrm{N}$ & 24.2 & 6.7 & 20 & 16.0 & 0 & 0 & $* * *$ \\
\hline Rhodeus amarus & Bitterling & $\mathrm{N}$ & 25.4 & 8.4 & 71.0 & 0.8 & 0 & 0 & $* * *$ \\
\hline Rutilus rutilus & Roach & $\mathrm{N}$ & 56.2 & 11.2 & 80 & 5.9 & 0 & 1.6 & $* * *$ \\
\hline Salaria fluviatilis & Freshwater blenny & $\mathrm{N}$ & 0.2 & 0.6 & 2.0 & 0 & 0 & 1.6 & ns \\
\hline Salmo salar & Atlantic salmon & $\mathrm{N}$ & 14.5 & 32.7 & 11.0 & 63.3 & 35.4 & 0 & $* * *$ \\
\hline Salmo trutta & Brown trout & $\mathrm{N}$ & 56.2 & 76.6 & 1.0 & 65.4 & 99.7 & 88.6 & $* * *$ \\
\hline Salvelinus fontinalis & Brook trout & NNE & 3.2 & 18.5 & 2.0 & 0.8 & 44.1 & 2.2 & $* * *$ \\
\hline Sander luciopercia & Pike-perch & $\mathrm{NE}$ & 22.7 & 11.7 & 98.0 & 1.3 & 0 & 0 & $* * *$ \\
\hline $\begin{array}{l}\text { Scardinius } \\
\text { erythrophtalmus }\end{array}$ & Rudd & $\mathrm{N}$ & 39.2 & 12.2 & 96.0 & 4.2 & 0 & 0 & $* * *$ \\
\hline Silurus glanis & European catfish & IE & 17.3 & 11.1 & 95.0 & 0.4 & 0 & 0 & $* * *$ \\
\hline Squalius cephalus & European chub & $\mathrm{N}$ & 57.3 & 15.0 & 65.0 & 3.8 & 0.3 & 29.9 & $* * *$ \\
\hline Telestes muticellus & Italian riffle dace & END & $<0.1$ & 0.1 & 0 & 0 & 0 & 0.5 & ns \\
\hline Telestes souffia & Souffia & $\mathrm{N}$ & 9.3 & 15.5 & 2.0 & 0 & 0.6 & 70.7 & $* * *$ \\
\hline Thymallus thymallus & Grayling & $\mathrm{N}$ & 7.0 & 7.5 & 6.0 & 2.5 & 6.7 & 16.3 & $* * *$ \\
\hline Tinca tinca & Tench & $\mathrm{N}$ & 37.9 & 9.5 & 80 & 0.8 & 0 & 0 & $* * *$ \\
\hline Zingel asper & Apron & END & 0.2 & 0.7 & 0 & 0 & 0 & 3.3 & $*$ \\
\hline
\end{tabular}

a Origin: $\mathrm{N}=$ native; $\mathrm{NE}=$ naturalized exotic; $\mathrm{NNE}=$ non-naturalized exotic; $\mathrm{IE}=$ invasive exotic .

bignificance of the Fisher exact test

***: $p<0.001 ; * *: p<0.01 ; *: p<0.05$; ns: non-significant; abs: absent in the priority subcatchments.

covers present in the drainage catchment upstream of the considered subcatchment. We kept the first axis of this PCA that accounted for $98.1 \%$ of the total variability to define the position of each subcatchment along a gradient of land-use ranging from 0 (agriculture) to 1 (forest).

We lastly ensured that the 11 selected environmental predictors were not strongly correlated (all Spearman correlation coefficients $<0.7$ ).

\section{Ensemble modelling of fish species distribution}

Species distribution models (SDM) were used to relate the observed fish spatial distribution to the set of environmental predictors (Guisan and Zimmermann, 2000; Elith and Leathwick, 2009). We applied six statistical methods available within the BIOMOD framework (Thuiller et al., 2009) of the R software ( $R$ Development Core Team, 2012) with default settings to our dataset: generalized linear models, generalized additive models, generalized boosted models, classification tree analyses, artificial neural networks and random forests. We then computed the consensus model (i.e. the mean value) between the outputs of these six SDM to get the final probabilities of occurrence for each species (Marmion et al., 2009). For each SDM and for each species, we replicated 10 runs by randomly selecting $70 \%$ of the sampled subcatchments for model calibration and 30\% 
of the data set aside for independent evaluation of SDM performances (Fielding and Bell, 1997; Elith and Leathwick, 2009). The consensus model was evaluated via the Area Under the Curve (AUC) of the Receiver Operating Characteristic (ROC) which is a measure of the ratio of the true presences (i.e. accurately predicted) and the false presences (i.e. wrongly predicted). We considered that a model with an AUC value $\geq 0.750$ was indicative of good predictive performances (Pearce and Ferrier, 2000; Strecker et al., 2011).

For each species, we then selected the threshold that maximized simultaneously the number of true presences and true absences to convert the predicted probabilities of occurrence into presence/absence predictions (Fielding and Bell, 1997). For each of the 6097 planning units, the species predicted as being present were pooled to obtain the predicted fish assemblage. As recommended by Stockwell and Peterson (2002), the species occurring too rarely in the dataset (less than 25 presences; 14 species concerned) were not modelled. The observed occurrences of these species were consequently pointed and added to the final predictions of fish assemblages as it is usually done with scarce species in conservation planning studies (e.g. Leathwick et al., 2010; Strecker et al., 2011).

\section{Definition of the diversity-based conservation objectives}

Based on the predicted fish assemblages, we computed nine indices for each of the 6,097 planning units. These indices can be assigned to four aspects of diversity: taxonomic diversity, functional diversity, natural heritage importance and socio-economic value. Each of these aspects of diversity was considered as a single objective for the present conservation planning assessment (Maire et al., 2013).

First, the taxonomic diversity of each fish assemblage was evaluated by considering the species richness, the rangesized rarity of the species present (Rarity Index; Fattorini, 2006) and the originality (i.e. rarity) of the assemblage relative to the assemblages present in the other subcatchments (Maire et al., 2013).

Second, 21 biological traits that ecologically and functionally describe each species (Buisson et al., 2013; Maire et al., 2013) were used to assess the functional diversity of fish assemblages. Based on these traits, we computed three indices: the functional originality (Buisson et al., 2013), the functional uniqueness (Buisson et al., 2013) and the trait diversity (Buisson and Grenouillet, 2009).

Third, the natural heritage importance of each fish assemblage was determined by considering the conservation status (Biodiversity Conservation Concern index; Fattorini, 2006) and the biogeographical origin (Origin Index; Bergerot et al., 2008) of the species present.
Last, an index reflecting the different levels of fishing interest of each species (Fishing Interest Index; Maire et al., 2013) was computed to assess the socio-economic value of the fish assemblages.

More details about these indices are available in Appendix S1 and Maire et al. (2013).

We then standardized the nine indices using a '0-1 scaling' procedure (Sneath and Sokal, 1973) to ensure that they were comparable (Maire et al., 2013). The values of the indices thus range from 0 (low conservation interest) to 1 (high conservation interest). The indices were then summed within each aspect of diversity to obtain a single value for each conservation objective. We also standardized the conservation objectives between 0 and 1 to make them comparable. We lastly computed Spearman correlation coefficients between each of the conservation objectives to assess their redundancy.

\section{Multi-objective prioritization using Pareto optimality ranking}

To obtain a single value of conservation priority for each of the 6097 planning units (i.e. subcatchments) that takes into account the four conservation objectives, we have applied an approach based on the Pareto optimality principle (Reynolds and Ford, 1999; Zitzler and Thiele, 1999). This principle has been identified as one of the most suitable methods to solve multi-objective optimization problems in various scientific fields (Ascough et al., 2008; Moilanen et al., 2009; Irisarri et al., 2011; Firn et al., 2015). The Pareto optimality principle is built on the relationship of dominance between solutions (here, planning units). A solution is defined as non-dominated if no other solution presents higher values for all objectives simultaneously (Kennedy et al., 2008; Kramer et al., 2013). The solutions that are not dominated by any other solutions belong to the first Pareto rank and represent the planning units of highest conservation priority (i.e. the optimal trade-off alternatives among the four conservation objectives that cannot be objectively differentiated; Rothley, 1999). Consequently, each planning unit is assigned to one single Pareto rank, from 1 to $N$ following a decreasing order of conservation priority, within which all the planning units are considered equivalent. The methodological intricacies of the Pareto optimality ranking are illustrated in Figure 1.

\section{Characterization of the top-ranked subcatchments}

According to Pareto optimality ranking (i.e. conservation priority), the 6097 subcatchments were divided into two groups: (i) the top-ranked subcatchments belonging to Pareto ranks from 1 to 3 ; and (ii) the subcatchments of 


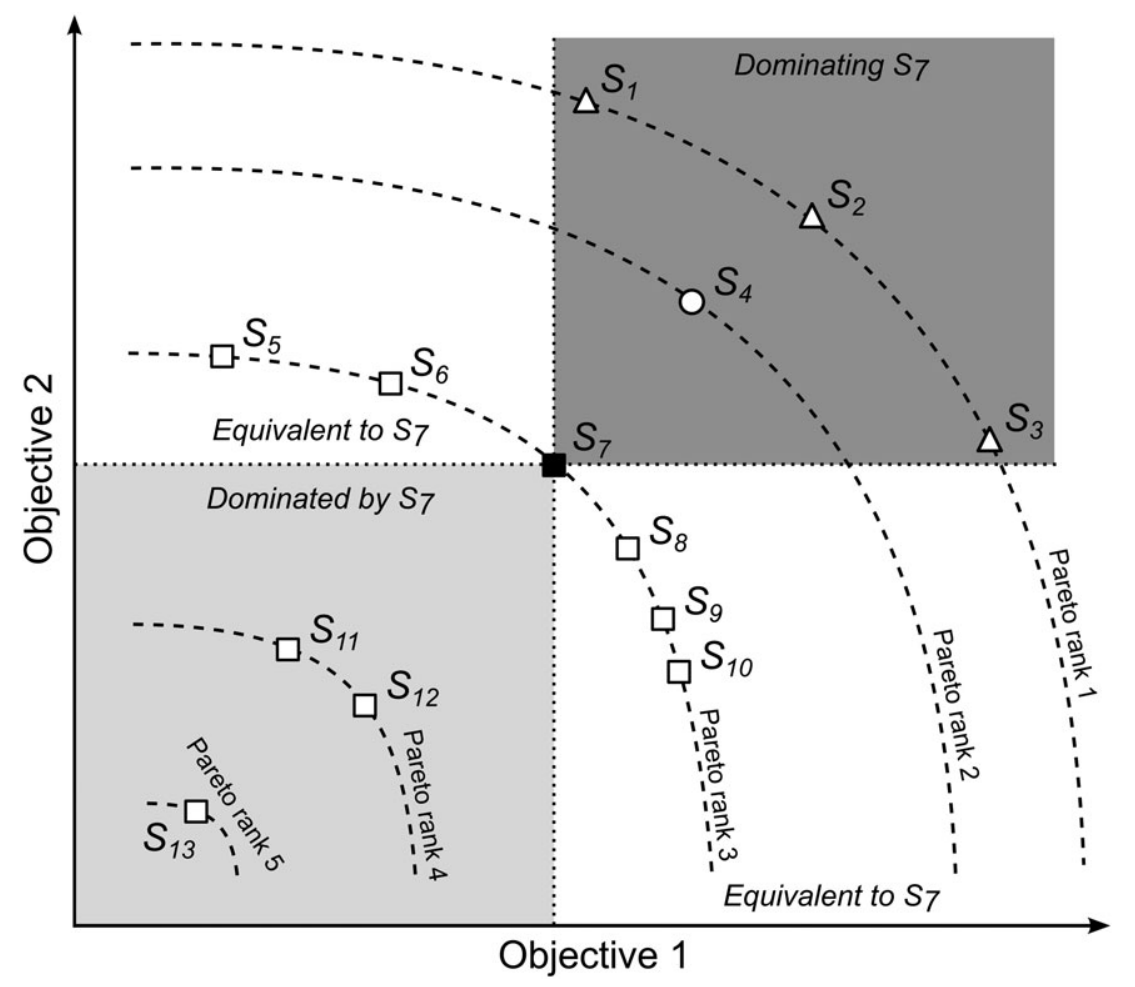

Figure 1. Schematic representation of the Pareto optimality ranking. For a better understanding, the example of a two-objective assessment was chosen, but the principle is similar with more than two objectives. Every plotted symbol represents a 'solution' $\left(S_{i}\right)$ to rank. The different Pareto dominance relationships to solution $S_{7}$ are shown. Three cases are possible: (i) $S_{7}$ presents higher values for all objectives than other solutions $\left(S_{11}\right.$ to $\left.S_{13}\right)$ which means that $S_{7}$ is dominating these solutions based on the Pareto optimality principle; (ii) $S_{7}$ presents lower values for all objectives than other solutions $\left(S_{1}\right.$ to $\left.S_{4}\right)$ indicating that these areas are dominating $S_{7}$; and (iii) $S_{7}$ presents a higher value for at least one objective but the other solutions present a higher value for at least another objective $\left(S_{5}, S_{6}\right.$ and $S_{8}$ to $\left.S_{10}\right)$ which leads to equivalent (i.e. not comparable) solutions on the basis of the Pareto optimality principle. By applying the principle of Pareto optimality ranking, each solution can be ranked relatively to the others: the solutions that are not dominated by any solutions form the first Pareto rank ( $S_{1}$ to $S_{3}$; triangles); the solutions that are solely dominated by the solutions of the first rank form the second Pareto rank $\left(S_{4}\right.$; circle), and so forth until all the solutions are assigned to a specific Pareto rank

lower conservation priority belonging to Pareto ranks equal or higher than 4 . This partitioning in two groups represents a fair compromise between a good discrimination and a sufficient number of priority subcatchments to allow various management alternatives. We have thereafter focused only on the group of subcatchments of highest conservation priority (hereafter, priority subcatchments). A hierarchical cluster analysis (HCA) was applied to the fish assemblages of the priority subcatchments to identify clusters of fish assemblages. Then, the difference of occurrence of each species (i.e. percentage of subcatchments where the species was predicted as present) between clusters was tested using Fisher exact tests. The environmental differences (e.g. location along the upstream-downstream gradient, drainage area, altitude) of the priority subcatchments between clusters were investigated using Kruskal-Wallis tests, which were followed by a Dunn's post-hoc test to compare each pair of clusters when the difference was significant.

\section{RESULTS}

The modelling procedure resulted in models with accurate predictive performances for most species (see Table S1). Among the 6097 subcatchments, 4178 different fish assemblages were predicted (i.e. at least one species differed between them), and 3532 (57.9\%) subcatchments presented unique fish assemblages (i.e. predicted only once among all the 6097 subcatchments).

Based on the predicted fish assemblages, the nine indices were computed, and then assembled to get the four conservation objectives (Figure 2). The greatest absolute Spearman correlation was found between the taxonomic diversity and the natural heritage importance but remains low $(\rho=-0.385)$, indicating that the conservation objectives were not strongly correlated. They were thus not redundant and evaluated distinct conservation features. Among the most noteworthy patterns, it appeared that the downstream part of the large rivers presents high 


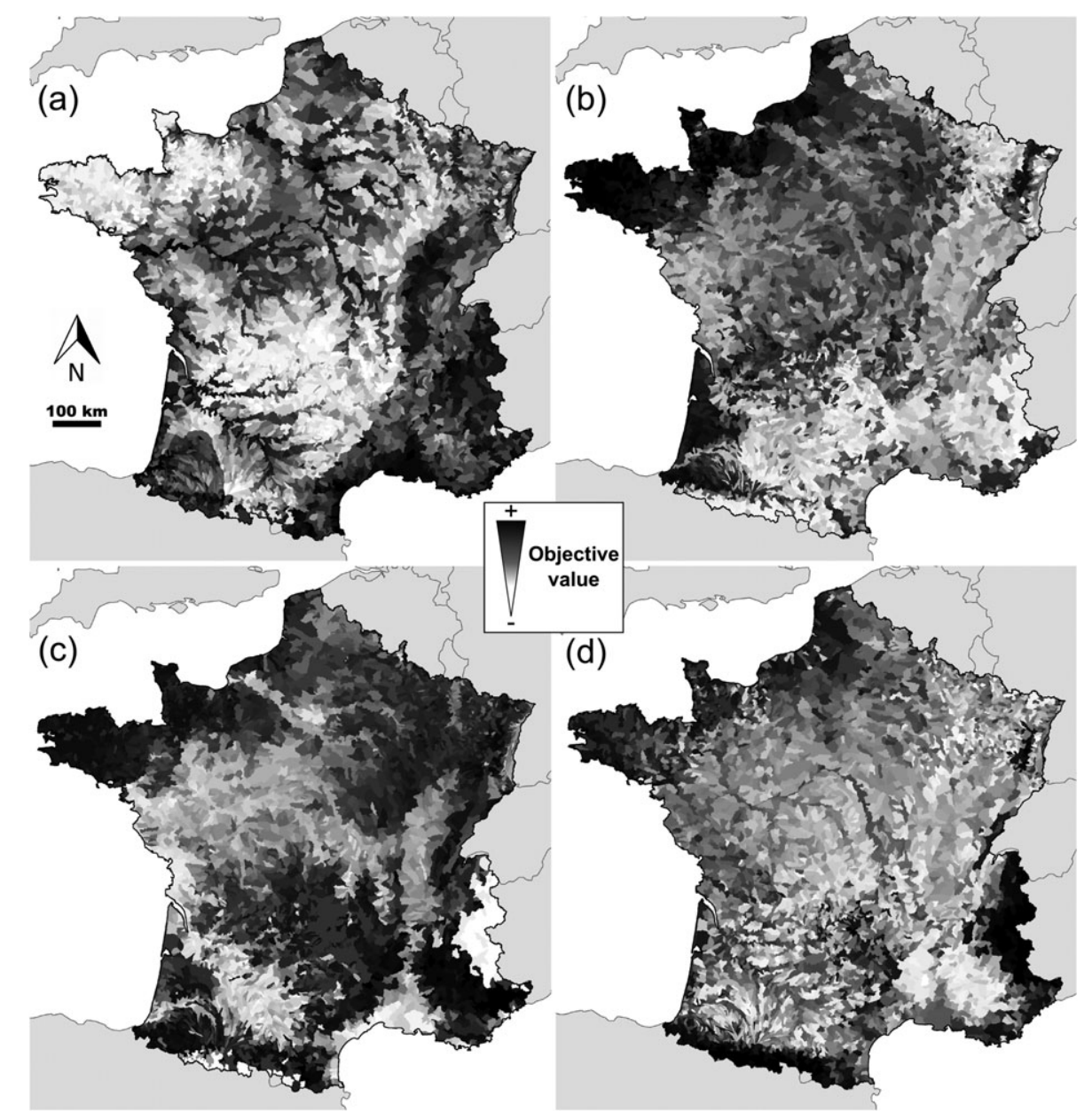

Figure 2. Values of the conservation objectives: (a) taxonomic diversity, (b) functional diversity, (c) natural heritage importance and (d) socioeconomic value. Planning units are ranked from low (areas in light gray) to high (areas in black) objective value through a grayscale

values of taxonomic diversity but low natural heritage importance. The small coastal catchments display great values of both functional diversity and natural heritage importance while they are poorly ranked according to their taxonomic diversity. The mountain ranges show great socio-economic value but generally a quite low functional diversity.

The Pareto optimality ranking resulted in the classification of the 6097 subcatchments into 20 distinct Pareto ranks, from highest (1st Pareto rank) to lowest (20th Pareto rank) conservation priorities (Figure 3). Each rank comprised 305 subcatchments on average (standard deviation $=186$ ). A total of 866 priority subcatchments (i.e. Pareto ranks $\leq 3$ ) was identified, which represented about $14 \%$ of the entire French hydrographic network. Most of them were (i) headwater streams located in the mountain ranges (i.e. the Alps, the Pyrenees and the Vosges); (ii) small coastal streams (i.e. the English Channel basins, the South Atlantic basins and the Mediterranean basins); or (iii) the downstream part of the main axis of the major rivers (i.e. the Loire, the Seine, the Garonne and the Rhône rivers). In contrast, the lowland tributaries of the Garonne and Loire rivers, as well as some of the subcatchments of the South Atlantic basins (e.g. the Charente River), presented the lowest conservation priorities.

The hierarchical clustering of the priority subcatchments based on the composition of fish assemblages resulted in the identification of four clusters (Figure 4). Species occurrences between clusters were significantly different for most species (Fisher exact test, $p<0.001$ ), except for the scarcest ones, such as freshwater blenny Salaria fluviatilis or twaite shad Alosa fallax fallax (Table I). The cluster I is dominated by limnophilic species (e.g. common bream Abramis brama, roach Rutilus rutilus, tench Tinca tinca), which are mostly cyprinid species or amphihaline species (e.g. flounder Platichthys flesus, thick-lipped grey mullet Chelon labrosus). The cluster II includes fish assemblages dominated by brown trout Salmo trutta and European eel 


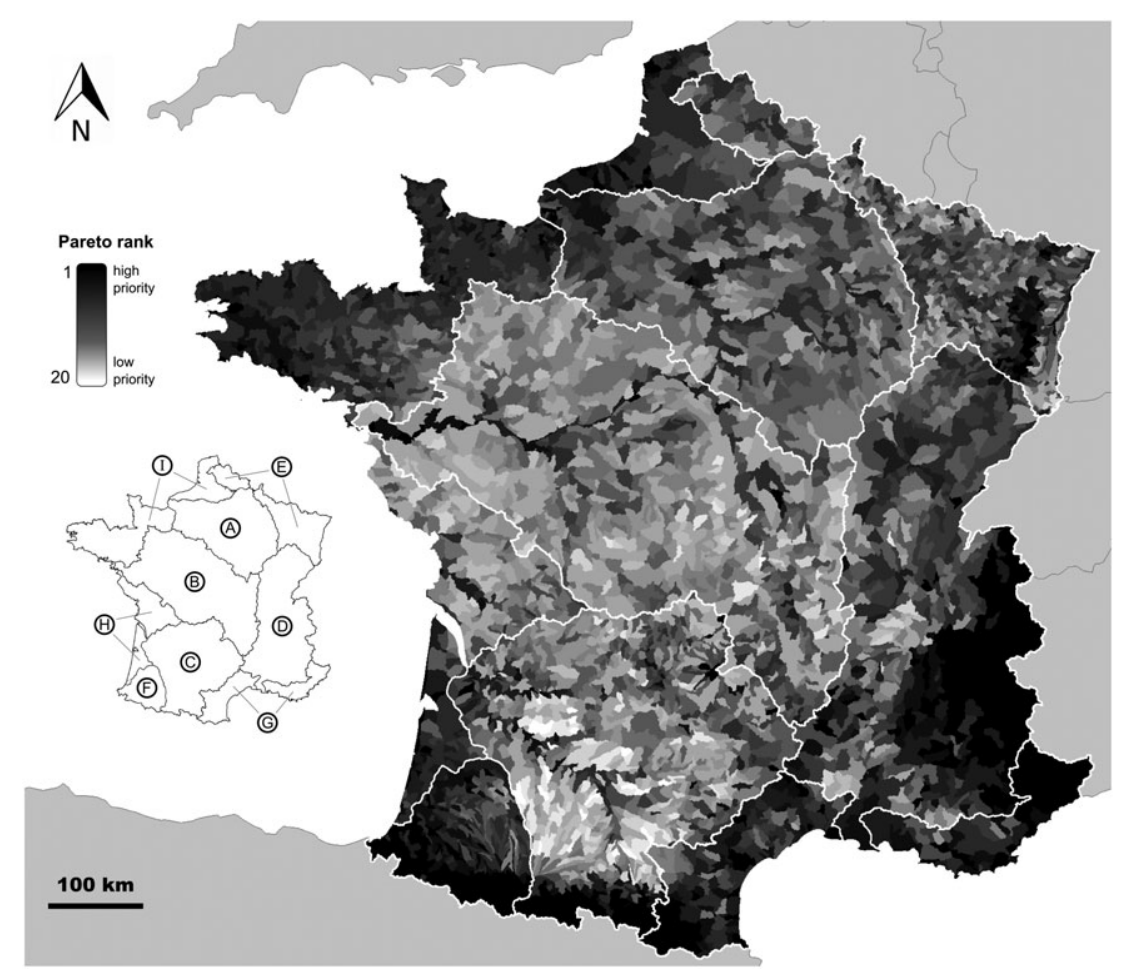

Figure 3. Conservation priorities for freshwater fish in France resulting from the Pareto optimality ranking. Planning units are ranked from the first (highest conservation priority; areas in black) to the last (lowest conservation priority; areas in light gray) Pareto ranks through a grayscale. The nine French hydro-ecoregions (delimited by the white lines) are identified on the inserted map on the left: (A) Seine basin, (B) Loire basin, (C) Garonne basin, (D) Rhône basin, (E) North Sea basins, (F) Adour basin, (G) Mediterranean basins, (H) South Atlantic basins and (I) English Channel basins

Anguilla anguilla, which are generally accompanied by several species such as stone loach Barbatula barbatula, brook lamprey Lampetra planeri or Atlantic salmon Salmo salar. The cluster III is defined by high occurrences of salmonid species, especially the brown trout, with few additional species (e.g. common bullhead Cottus gobio). Last, the cluster IV has great occurrences of Mediterranean species (e.g. Southern barbel Barbus meridionalis, souffia Telestes souffia) and brown trout. Except for two extremely scarce species (i.e. Lez sculpin Cottus petiti and Italian loach Cobitis bilineata), all the species were represented in the priority subcatchments, generally covering a good proportion of their predicted distribution (Table I). Moreover, several species such as the brown trout, the Atlantic salmon and the Southern barbel have a higher percentage of occurrence in the priority subcatchments than in the entire studied region.

The nine hydro-ecoregion (HER) had different overall degree of conservation priority (Table II). The Loire and Seine basins had a very low conservation priority with only $2.3 \%$ and $3.1 \%$ of their subcatchments belonging to Pareto ranks from 1 to 3, respectively. The South Atlantic, North Sea, Garonne and English Channel basins had low to moderate conservation priority with about $7-15 \%$ of their subcatchments in the first three Pareto ranks. In contrast, the Rhône, Mediterranean and Adour basins showed high overall conservation priorities with more than $30 \%$ of their subcatchments in Pareto ranks $\leq 3$, even reaching $53.3 \%$ for the Adour basin. In addition, while the English Channel, Loire, Seine and South Atlantic basins had priority subcatchments only belonging to two clusters (i.e. two different kinds of fish assemblages), some HER presented three different clusters (i.e. Adour, Garonne, North Sea and Rhône basins), and the four types of fish assemblages were all represented within the Mediterranean basins (Table II).

The priority subcatchments were also found to be highly distinct on the basis of their environmental features (Figure 5). Indeed, most of the subcatchments of the cluster I are located at low altitude, downstream of large catchments whereas those of the cluster III are generally located upstream in forested areas of high altitude. The subcatchments of the cluster II are usually part of relatively small coastal catchments (i.e. subcatchments of low altitude with small drainage areas evenly distributed along the upstreamdownstream gradient). Last, the cluster IV is characterized by forested subcatchments mostly located upstream, at medium altitude. 


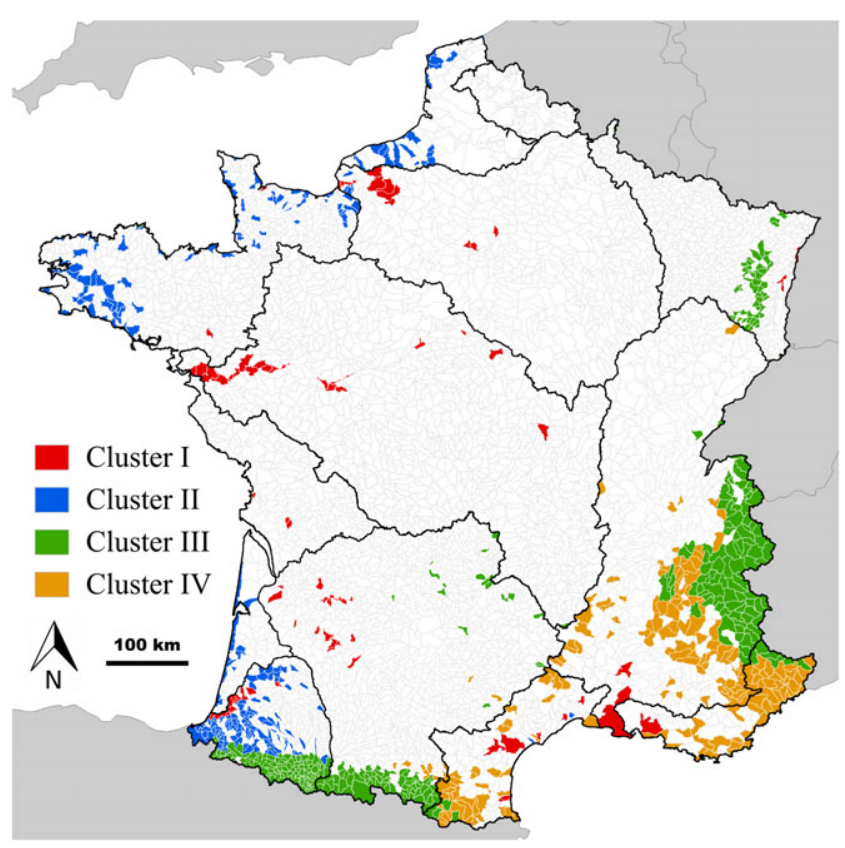

Figure 4. Spatial location of the priority subcatchments (Pareto rank $\leq 3$ ) grouped according to the results of the hierarchical cluster analysis performed on the composition of fish assemblages.

[Colour figure can be viewed at wileyonlinelibrary.com]

\section{DISCUSSION}

\section{Diversity-based conservation objectives and Pareto optimality ranking}

We have developed a prioritization framework that focuses on different aspects of the diversity of fish assemblages instead of the raw spatial distribution of species. This framework allows targeting criteria relevant to biodiversity conservation, and provides the opportunity to examine simultaneously many aspects of diversity rather than being limited to a taxonomic approach (Maire et al., 2015). Furthermore, by considering several aspects of diversity that are not redundant, it is possible to take many species characteristics into account (Maire et al., 2013). For instance, an assemblage made up of numerous but invasive and functionally redundant species would be poorly ranked using our framework, whereas it is likely to obtain a much higher conservation priority from a solely taxonomic assessment.

Diversity-based methods may however imply a redundancy in species composition among planning units of high conservation priority (Justus and Sarkar, 2002). For instance, it is possible that two planning units belonging to the first Pareto rank hold exactly the same assemblage of species, thus decreasing the interest of protecting both of them, especially if they are spatially close together. Given the numerous distinct and unique fish assemblages predicted by our models, this issue was however strongly lessened in this study.

We have applied Pareto optimality ranking to limit the subjectivity of our assessment. Indeed, this approach does not require to relatively weight the conservation objectives (Arthur et al., 2004), which is classically done on the basis of expert judgment or by equally weighting the different objectives (e.g. Bergerot et al., 2008; Maire et al., 2013). However, the Pareto optimality ranking is likely to provide a less discriminant prioritization when the number of planning units is small (i.e. when only few Pareto ranks are identified), which may be less suitable to support environmental decision-making. Hence, when both the spatial extent and the number of planning units make it applicable, the Pareto optimality ranking provides a robust classification of the planning units in ranks within which they cannot be objectively differentiated (Rothley, 1999; Firn et al., 2015). The decision-makers can then choose between planning units that are equally important to protect, thus leaving the possibility to account for non-ecological aspects (e.g. feasibility, costs, land conflicts) in the decision procedure. This is a strength of the Pareto optimality ranking given that local opportunities for protection are mainly driven by political and socio-economic considerations (Ascough et al., 2008),

Table II. Number of priority subcatchments (i.e. Pareto rank $\leq 3$ ) by hydro-ecoregion and by cluster. The total number and the percentage (in brackets) of priority subcatchments by hydro-ecoregion are also indicated. Refer to Figure 3 for the location of the hydro-ecoregions

\begin{tabular}{|c|c|c|c|c|c|}
\hline Hydro-ecoregion & Cluster I & Cluster II & Cluster III & Cluster IV & Total \\
\hline Adour & 13 & 99 & 106 & & $218(53.3 \%)$ \\
\hline English Channel & 2 & 111 & & & $113(14.9 \%)$ \\
\hline Garonne & 24 & & 86 & 11 & $121(9.2 \%)$ \\
\hline Loire & 23 & & 1 & & $24(2.3 \%)$ \\
\hline Mediterranean & 8 & 2 & 10 & 84 & $104(45.6 \%)$ \\
\hline North Sea & 10 & 2 & 50 & & $62(7.5 \%)$ \\
\hline Rhône & 3 & & 91 & 89 & $183(30.3 \%)$ \\
\hline Seine & 14 & 5 & & & $19(3.1 \%)$ \\
\hline South Atlantic & 3 & 19 & & & $22(6.7 \%)$ \\
\hline All & 100 & 237 & 345 & 184 & $866(14.2 \%)$ \\
\hline
\end{tabular}



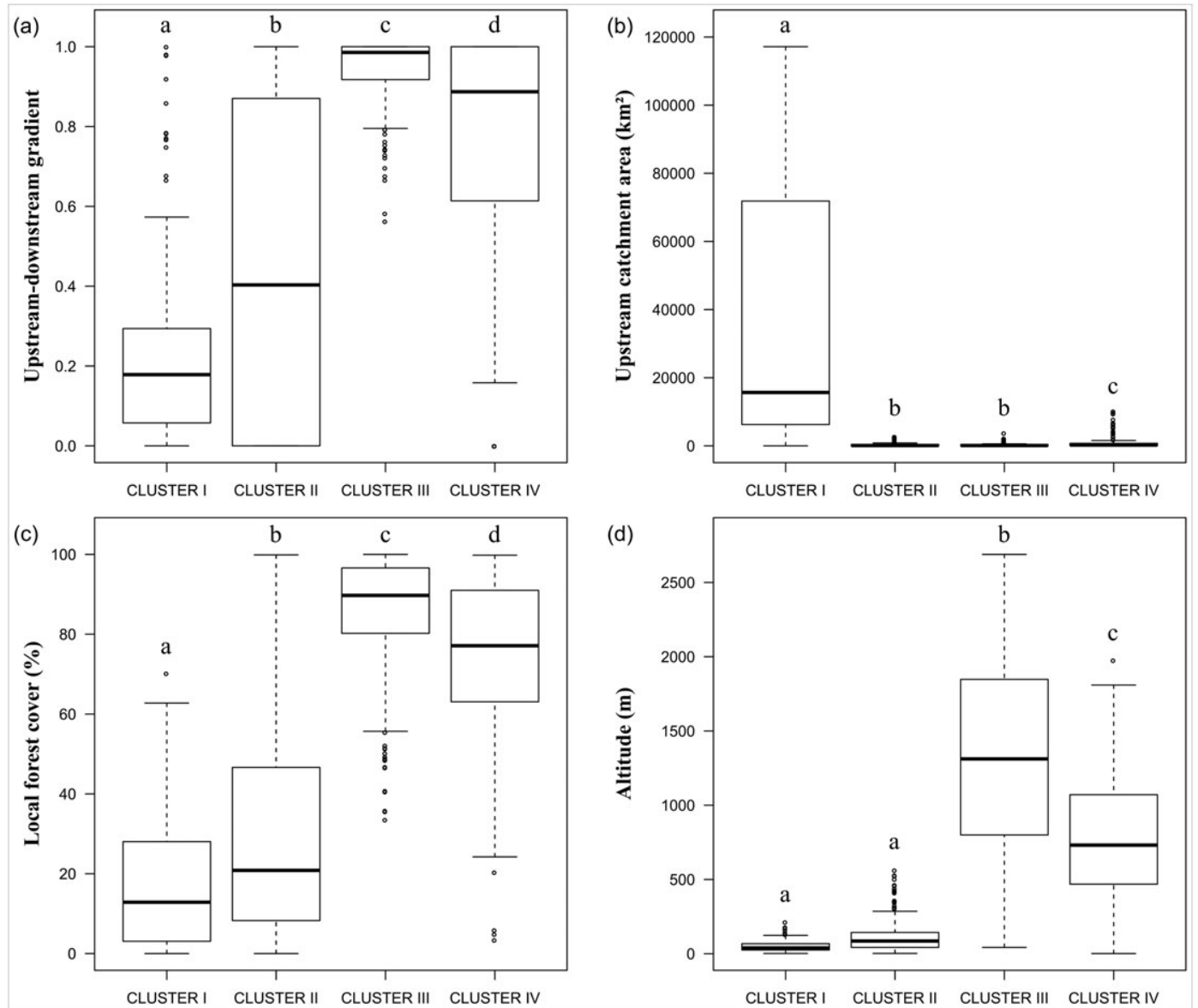

Figure 5. Environmental features of the priority subcatchments (Pareto rank $\leq 3$ ) according to the clusters identified by the hierarchical cluster analysis: (a) relative location of the subcatchments along the upstream-downstream gradient, ranging from 0 (mouth) to 1 (source), (b) area of the drainage catchment upstream of the subcatchments $\left(\mathrm{km}^{2}\right)$, (c) percentage of forest land-cover in the subcatchments $(\%)$ and $(\mathrm{d})$ mean altitude of the subcatchments $(\mathrm{m})$. The median is denoted by the bold horizontal line, the box delimits the interquartile range and the whisker lines extend to the observed maxima and minima, except for the outliers symbolized by circles. All the four environmental variables were significantly different between clusters (Kruskal-Wallis tests, $p<0.001$ ). The letters displayed above each boxplot illustrate the results of the Dunn's post-hoc tests $(p<0.05)$. Different letters reflect significant differences between clusters

whose intricacies are often hard to quantify a priori (Estévez et al., 2013). Indeed, the quantification of such complex and often divergent parameters as well as their inclusion in conservation planning studies remain a great challenge and represent a major prospect to develop more inclusive prioritization methods (Naidoo et al., 2006; Knight et al., 2011). However, the identification of a set of priority areas for protection presenting high-quality trade-offs between the conservation objectives is still an advantageous solution (Ascough et al., 2008; Kramer et al., 2013).

\section{Implications for river management in France}

Several features of riverine hydrosystems that should be considered to build feasible and efficient conservation plans are now widely-acknowledged. First, management actions should be conducted at the scale of the whole catchment whenever possible to insure an efficient protection of aquatic ecosystems and to strongly limit the exogenous threats affecting them (Keith, 2000; Saunders et al., 2002; Abell et al., 2007; Laffaille and Brosse, 2011). This is however not always possible, especially for large catchments (Collares-Pereira and Cowx, 2004). In such cases, management efforts should target the less impacted subcatchments, such as headwater streams and/or highly forested subcatchments, which are likely to present unique habitats hosting unique species (Saunders et al., 2002; Meyer et al., 2007). Second, several studies have emphasized that the aquatic environments required to complete the entire life cycle of the species considered must be protected, including for instance the downstream reaches whose good ecological status and accessibility are mandatory for migratory species (Collares-Pereira and Cowx, 2004; Dudgeon et al., 2006). Third, the willingness and capacity of actions of local 
stakeholders are crucial to the management process, given that they are directly linked to conservation opportunities (Collares-Pereira and Cowx, 2004). Last, accounting for the trade-offs between conservation of freshwater environments and human use of ecosystem goods and services is also essential (Dudgeon et al., 2006).

The present prioritization framework classified the 6097 French subcatchments into 20 ranks of decreasing conservation priority. Although a great diversity of priority subcatchments for protection has been identified regarding both their environmental and biological features, most of the priority subcatchments identified in our study closely met one or several of these widely accepted criteria. First, the subcatchments belonging to the cluster I are essentially located in the downstream part of large catchments such as the Loire, Seine, Rhône and Garonne rivers. Consistent with the findings of Lasne et al. (2007) and Laffaille et al. (2011), we found that the typical fish assemblage of this cluster includes many different cyprinid and/or migratory species, resulting in assemblages of high taxonomic diversity and socio-economic value, in spite of the concomitant presence of several non-native species. This assemblage is typical of the bream zone of the Huet zonation (Huet, 1959). Yet, the protection of these downstream subcatchments would probably conflict with human activities which are very dense in these urban, agricultural and industrialized areas, but also owing to their large upstream drainage areas which are difficult to entirely protect. Second, the fish assemblages of the cluster II are typical of small coastal catchments of Western Europe (Laffaille et al., 2011), mainly characterized by the combined presence of the brown trout and the European eel along with some auxiliary species (e.g. stone loach, Celtic bullhead Cottus perifretum). These assemblages are of great natural heritage importance and socioeconomic value, also showing a good functional diversity but a quite low taxonomic diversity. The subcatchments belonging to the cluster II are all part of relatively small catchments. This may therefore represent good opportunities to implement management strategies that integrate a wholecatchment perspective (Keith, 2000), even if they are likely to present dense human activities (e.g. urban areas, tourism, fisheries). Yet, few studies have investigated the importance of protecting these small coastal catchments despite their potentially high conservation effectiveness (but see Maire et al., 2015). The cluster III groups fish assemblages mainly made up of salmonid species located in upstream reaches in the major mountain ranges (i.e. Alps, Pyrenees and Vosges mountains). These fish assemblages show great natural heritage importance and socio-economic value. They are typical of the trout zone (Huet, 1959), which corresponds to the most upstream part of hydrographic networks. Such headwater and forested regions are among the most crucial ones to protect in France. This finding is supported by other studies that have emphasized the originality of the fish assemblages and the vulnerability of the ecosystems of these regions, especially to climate change (e.g. Buisson and Grenouillet, 2009; Filipe et al., 2013). They seem to be particularly suitable for the implementation of management actions, given the low density of human activities and the small extent of their upstream drainage areas (Laffaille and Brosse, 2011). Last, the subcatchments of the cluster IV are all found in Mediterranean regions (i.e. South East of France), most of them being located at medium altitude with relatively small upstream drainage areas. The fish assemblages of this cluster have a high taxonomic diversity and a great natural heritage importance. They include fish species only observed in these regions (e.g. Mediterranean barbel, souffia) and several salmonid species (e.g. brown trout, grayling Thymallus thymallus). This finding is consistent with other studies that have emphasized the crucial importance of Mediterranean streams for conservation, because they host unique and highly vulnerable fish species (Hermoso et al., 2009; Filipe et al., 2013). Moreover, the Mediterranean basin has been identified as one of the 25 global biodiversity hotspots (Myers et al., 2000), as well as one of the regions of the world facing the highest risk of biological invasions (Gozlan, 2012).

The priority subcatchments identified herein are characterized by contrasted fish assemblages, which appear to be complementary in terms of species composition. These priority subcatchments are unevenly distributed among the nine French hydro-ecoregions, which allows the identification of regions where conservation efforts should be concentrated. Indeed, the Mediterranean and Adour basins show an exceptionally high potential for the protection of fish biodiversity with three to four different clusters represented, as well as the Rhône and Garonne basins to a lesser extent.

\section{CONCLUSION}

The method proposed in this study ranks the planning units in a way that maximizes the biological benefits potentially provided by the conservation of the top-ranked planning units. The application of this prioritization approach to the fish assemblages of France has resulted in the identification of four distinct types of priority subcatchments. Two of them are typical of the hydrographic zonation of Huet (1959) (i.e. trout and bream zones), while the other two (i.e. small coastal catchments of western France and Mediterranean streams) are original, unique and spatially restricted regions. These four types of hydrosystems host specific and original fish assemblages that would be complementary and representative of the fish fauna of France if they were concurrently protected. Yet, in a national-scale study conducted 15 years ago, Keith (2000) 
showed that the network of protected areas was insufficient to protect fish biodiversity in France, emphasizing the urgent need of setting up additional efforts for river management at the national level. Hence, the outcomes of the present study are very positive and promising for the conservation of freshwater fish in France: most of the priority areas are located in regions that seem practically suitable for the implementation of conservation actions, being either headwater subcatchments facing limited human impacts or small coastal subcatchments convenient for a comprehensive management.

\section{ACKNOWLEDGEMENTS}

This research is part of the PrioFish project which has been funded by the Fondation pour la Recherche sur la Biodiversité, the Conseil Régional Nord-Pas-de-Calais and the Agence de l'Eau Artois-Picardie. We are indebted to the French National Agency for Water and Aquatic Environment (ONEMA) for providing fish data, and we would like to thank the many fieldworkers who contributed to the fish records. We are grateful to the two anonymous referees for their suggestions that have improved the manuscript.

\section{REFERENCES}

Abell R, Allan J, Lehner B. 2007. Unlocking the potential of protected areas for freshwaters. Biological Conservation 134: 48-63. DOI:10.1016/j. biocon.2006.08.017.

Arthur JL, Camm JD, Haight RG, Montgomery CA, Polasky S. 2004. Weighing conservation objectives: maximum expected coverage versus endangered species protection. Ecological Applications 14: 1936-1945. DOI: $10.1890 / 02-5360$.

Ascough JC, Maier HR, Ravalico JK, Strudley MW. 2008. Future research challenges for incorporation of uncertainty in environmental and ecological decision-making. Ecological Modelling 219: 383-399. DOI:10.1016/j.ecolmodel.2008.07.015.

Bergerot B, Lasne E, Vigneron T, Laffaille P. 2008. Prioritization of fish assemblages with a view to conservation and restoration on a large scale European basin, the Loire (France). Biodiversity and Conservation 17: 2247-2262. DOI:10.1007/s10531-008-9331-6.

Bossard M, Feranec J, Othael J. 2000. CORINE Land Cover Technical Guide-Addendum 2000. European Environment Agency. Technical Report available at: http://www.eea.europa.eu/publications/tech40add. Accessed 15 February 2016.

Buisson L, Grenouillet G. 2009. Contrasted impacts of climate change on stream fish assemblages along an environmental gradient. Diversity and Distributions 15: 613-626. DOI:10.1111/j.1472-4642.2009.00565.x.

Buisson L, Grenouillet G, Villéger S, Canal J, Laffaille P. 2013. Toward a loss of functional diversity in stream fish assemblages under climate change. Global Change Biology 19: 387-400. DOI:10.1111/gcb.12056.

Caissie D. 2006. The thermal regime of rivers: a review. Freshwater Biology 51: 1389-1406. DOI:10.1111/j.1365-2427.2006.01597.x.

Céréghino R, Santoul F, Compin A, Figuerola J, Mastrorillo S. 2005. Cooccurrence patterns of some small-bodied freshwater fishes in southwestern France: implications for fish conservation and environmental management. AMBIO: A Journal of the Human Environment 34: 440-444. DOI:10.1579/0044-7447-34.6.440.

Collares-Pereira MJ, Cowx IG. 2004. The role of catchment scale environmental management in freshwater fish conservation. Fisheries Management and Ecology 11: 303-312. DOI:10.1111/j.13652400.2004.00392.x.

Collier KJ. 2011. The rapid rise of streams and rivers in conservation assessment. Aquatic Conservation: Marine and Freshwater Ecosystems 21: 397-400. DOI:10.1002/aqc.1196.

Darwall WRT, Vié J-C. 2005. Identifying important sites for conservation of freshwater biodiversity: extending the species-based approach. Fisheries Management and Ecology 12: 287-293. DOI:10.1111/j.13652400.2005.00449.x.

Dudgeon D, Arthington AH, Gessner MO, Kawabata ZI, Knowler DJ, Lévêque C, Naiman RJ, Prieur-Richard AH, Soto D, Stiassny MLJ et al. 2006. Freshwater biodiversity: importance, threats, status and conservation challenges. Biological Reviews 81: 163-182. DOI:10.1017/ S1464793105006950.

Elith J, Leathwick JR. 2009. Species distribution models: ecological explanation and prediction across space and time. Annual Review of Ecology, Evolution, and Systematics 40: 677-697. DOI:10.1146/annurev. ecolsys.110308.120159.

ESRI. 2011. ArcGIS Desktop: Release 10. Redlands: USA.

Estévez RA, Walshe T, Burgman MA. 2013. Capturing social impacts for decision-making: a Multicriteria Decision Analysis perspective. Diversity and Distributions 19: 608-616. DOI:10.1111/ddi.12058.

Fattorini S. 2006. A new method to identify important conservation areas applied to the butterflies of the Aegean Islands (Greece). Animal Conservation 9: 75-83. DOI:10.1111/j.1469-1795.2005.00009.x.

Fielding AH, Bell JF. 1997. A review of methods for the assessment of prediction errors in conservation presence/absence models. Environmental Conservation 24: 38-49. DOI:10.1017/S0376892997000088.

Filipe AF, Lawrence JE, Bonada N. 2013. Vulnerability of stream biota to climate change in Mediterranean climate regions: a synthesis of ecological responses and conservation challenges. Hydrobiologia 719: 331-351. DOI:10.1007/s10750-012-1244-4.

Firn J, Maggini R, Chadès I, Nicol S, Walters B, Reeson A, Martin TG, Possingham HP, Pichancourt J-B, Ponce-Reyes R et al. 2015. Priority threat management of invasive animals to protect biodiversity under climate change. Global Change Biology 21: 3917-3930. DOI:10.1111/ gcb.13034.

Gozlan RE. 2012. Mapping conservation priorities in the Mediterranean: the issue of non-native freshwater fish introductions. Fisheries Management and Ecology 19: 89-92. DOI:10.1111/j.13652400.2012.00853.x.

Guisan A, Zimmermann NE. 2000. Predictive habitat distribution models in ecology. Ecological Modelling 135: 147-186. DOI:10.1016/S0304-3800 (00)00354-9.

Hermoso V, Kennard MJ. 2012. Uncertainty in coarse conservation assessments hinders the efficient achievement of conservation goals. Biological Conservation 147: 52-59. DOI:10.1111/1365-2664.12454.

Hermoso V, Linke S, Prenda J. 2009. Identifying priority sites for the conservation of freshwater fish biodiversity in a Mediterranean basin with a high degree of threatened endemics. Hydrobiologia 623: 127-140. DOI:10.1016/j.biocon.2012.01.020.

Hermoso V, Cattarino L, Kennard MJ, Watts M, Linke S. 2015. Catchment zoning for freshwater conservation: refining plans to enhance action on the ground. Journal of Applied Ecology 52: 940-949. DOI:10.1007/ s10750-008-9653-0.

Hijmans RJ, Cameron SE, Parra JL, Jones PG, Jarvis A. 2005. Very high resolution interpolated climate surfaces for global land areas. International Journal of Climatology 25: 1965-1978. DOI:10.1002/ joc. 1276 . 
Huet M. 1959. Profiles and biology of Western European streams as related to fish management. Transactions of the American Fisheries Society 88: $155-163 . \quad$ DOI:10.1577/1548-8659(1959)88[155: PABOWE]2.0.CO;2.

Irisarri F-X, Laurin F, Leroy F-H, Maire J-F. 2011. Computational strategy for multiobjective optimization of composite stiffened panels. Composite Structures 93: 1158-1167. DOI:10.1016/j.compstruct.2010.10.005.

Justus J, Sarkar S. 2002. The principle of complementarity in the design of reserve networks to conserve biodiversity: a preliminary history. Journal Of Biosciences 27: 421-435. DOI:10.1007/BF02704970.

Kanno Y, Russ WT, Sutherland CJ, Cook SB. 2012. Prioritizing aquatic conservation areas using spatial patterns and partitioning of fish community diversity in a near-natural temperate basin. Aquatic Conservation: Marine and Freshwater Ecosystems 22: 799-812. DOI:10.1002/aqc.2266.

Keith P. 2000. The part played by protected areas in the conservation of threatened French freshwater fish. Biological Conservation 92: 265-273. DOI:10.1016/S0006-3207(99)00041-5.

Kennedy MC, Ford ED, Singleton P, Finney M, Agee JK. 2008. Informed multi-objective decision-making in environmental management using Pareto optimality. Journal of Applied Ecology 45: 181-192. DOI:10.1111/j.1365-2664.2007.01367.x.

Knight AT, Sarkar S, Smith R, Strange N, Wilson KA. 2011. Engage the hodgepodge: management factors are essential when prioritizing areas for restoration and conservation action. Diversity and Distributions 17: 1234-1238. DOI:10.1111/j.1472-4642.2011.00789.x.

Kramer DB, Zhang T, Cheruvelil KS, Ligmann-Zielinska A, Soranno PA. 2013. A multi-objective, return on investment analysis for freshwater conservation planning. Ecosystems 16: 823-837. DOI:10.1007/s10021013-9654-3.

Laffaille P, Brosse S. 2011. Gestion des poissons et des hydrosystèmes dulçaquicoles. In Les poissons d'eau douce de France. Biotope, Mèze; Muséum national d'histoire naturelle: Paris, France; 157-213.

Laffaille P, Brosse S, Ombredane D, Feunteun E. 2011. Richesse et organisation spatiale des communautés de poissons d'eau douce. In Les poissons d'eau douce de France. Biotope, Mèze; Muséum national d'histoire naturelle: Paris, France; 128-155.

Lasne E, Bergerot B, Lek S, Laffaille P. 2007. Fish zonation and indicator species for the evaluation of the ecological status of rivers: example of the Loire basin (France). River Research and Applications 23: 877-890. DOI:10.1002/rra.1030.

Leathwick JR, Moilanen A, Ferrier S, Julian K. 2010. Complementaritybased conservation prioritization using a community classification, and its application to riverine ecosystems. Biological Conservation 143: 984-991. DOI:10.1016/j.biocon.2010.01.012.

Linke S, Norris RH, Pressey RL. 2008. Irreplaceability of river networks: towards catchment-based conservation planning. Journal of Applied Ecology 45: 1486-1495. DOI:10.1111/j.13652664.2008.01520.x.

Maire A, Buisson L, Biau S, Canal J, Laffaille P. 2013. A multi-faceted framework of diversity for prioritizing the conservation of fish assemblages. Ecological Indicators 34: 450-459. DOI:10.1016/j. ecolind.2013.06.009.

Maire A, Buisson L, Canal J, Rigault B, Boucault J, Laffaille P. 2015. Hindcasting modelling for restoration and conservation planning: application to stream fish assemblages. Aquatic Conservation: Marine and Freshwater Ecosystems 25: 839-854. DOI:10.1002/aqc.2566.

Marmion M, Parviainen M, Luoto M, Heikkinen RK, Thuiller W. 2009. Evaluation of consensus methods in predictive species distribution modelling. Diversity and Distributions 15: 59-69. DOI:10.1111/j.14724642.2008.00491.x.

Meyer JL, Strayer DL, Wallace JB, Eggert SL, Helfman GS, Leonard NE. 2007. The contribution of headwater streams to biodiversity in river networks. Journal of the American Water Resources Association 43: 86-103. DOI:10.1111/j.1752-1688.2007.00008.x.

Moilanen A, Possingham HP, Polasky S. 2009. A mathematical classification of conservation prioritization problems. In Spatial Conservation Prioritization: Quantitative Methods and Computational Tools. Oxford University Press: Oxford, UK; 28-42.

Myers N, Mittermeier RA, Mittermeier CG, da Fonseca GAB, Kent J. 2000. Biodiversity hotspots for conservation priorities. Nature 403: 853-858. DOI: $10.1038 / 35002501$.

Naidoo R, Balmford A, Ferraro PJ, Polasky S, Ricketts TH, Rouget M. 2006. Integrating economic costs into conservation planning. Trends in Ecology \& Evolution 21: 681-687. DOI:10.1016/j. tree.2006.10.003.

Nel JL, Reyers B, Roux DJ, Cowling RM. 2009. Expanding protected areas beyond their terrestrial comfort zone: identifying spatial options for river conservation. Biological Conservation 142: 1605-1616. DOI:10.1016/j. biocon.2009.02.031.

Oberdorff T, Pont D, Hugueny B, Chessel D. 2001. A probabilistic model characterizing fish assemblages of French rivers: a framework for environmental assessment. Freshwater Biology 46: 399-415. DOI:10.1046/ j.1365-2427.2001.00669.x.

Pearce J, Ferrier S. 2000. Evaluating the predictive performance of habitat models developed using logistic regression. Ecological Modelling 133: 225-245. DOI:10.1016/S0304-3800(00)00322-7.

Pont D, Hugueny B, Oberdorff T. 2005. Modelling habitat requirement of European fishes: do species have similar responses to local and regional environmental constraints? Canadian Journal of Fisheries and Aquatic Sciences 62: 163-173. DOI:10.1139/f04-183.

Poulet N, Beaulaton L, Dembski S. 2011. Time trends in fish populations in metropolitan France: insights from national monitoring data. Journal of Fish Biology 79: 1436-1452. DOI:10.1111/j.10958649.2011.03084.x.

R Development Core Team R. 2012. R: A Language and Environment for Statistical Computing. Austria: Vienna.

Reynolds JH, Ford ED. 1999. Multi-criteria assessment of ecological process models. Ecology 80: 538-553. DOI:10.2307/176633.

Rothley KD. 1999. Designing bioreserve networks to satisfy multiple, conflicting demands. Ecological Applications 9: 741-750. DOI:10.1890/ 1051-0761(1999)009[0741:DBNTSM]2.0.CO;2.

Roux DJ, Nel JL, Fisher R-M, Barendse J. 2016. Top-down conservation targets and bottom-up management action: creating complementary feedbacks for freshwater conservation. Aquatic Conservation: Marine and Freshwater Ecosystems 26: 364-380. DOI:10.1002/aqc.2577.

Saunders DL, Meeuwig JJ, Vincent ACJ. 2002. Freshwater protected areas: strategies for conservation. Conservation Biology 16: 30-41. DOI: 10.1046/j.1523-1739.2002.99562.x.

Sneath PHA, Sokal RR. 1973. Numerical Taxonomy: The Principles and Practice of Numerical Classification. W. H. Freeman and Co.: San Francisco, USA.

Stockwell DR, Peterson AT. 2002. Effects of sample size on accuracy of species distribution models. Ecological Modelling 148: 1-13. DOI:10.1016/S0304-3800(01)00388-X.

Strayer DL, Dudgeon D. 2010. Freshwater biodiversity conservation: recent progress and future challenges. Journal of the North American Benthological Society 29: 344-358. DOI:10.1899/08-171.1.

Strecker AL, Olden JD, Whittier JB, Paukert CP. 2011. Defining conservation priorities for freshwater fishes according to taxonomic, functional, and phylogenetic diversity. Ecological Applications 21: 3002-3013. DOI:10.1890/11-0599.1.

Thuiller W, Lafourcade B, Engler R, Araújo MB. 2009. BIOMOD—a platform for ensemble forecasting of species distributions. Ecography 32: 369-373. DOI:10.1111/j.1600-0587.2008.05742.x. 
Vörösmarty CJ, McIntyre PB, Gessner MO, Dudgeon D, Prusevich A, Green P, Glidden S, Bunn SE, Sullivan CA, Reidy Liermann C et al. 2010. Global threats to human water security and river biodiversity. Nature 467: 555-561. DOI:10.1038/nature09440.

Wilson KA, McBride MF, Bode M, Possingham HP. 2006. Prioritizing global conservation efforts. Nature 440: 337-340. DOI:10.1038/ nature04366.

Zitzler E, Thiele L. 1999. Multiobjective evolutionary algorithms: a comparative case study and the strength Pareto approach. IEEE Transactions on Evolutionary Computation 3: 257-271. DOI:10.1109/ 4235.797969.

\section{SUPPORTING INFORMATION}

Additional supporting information may be found in the online version of this article at the publisher's web site.

Appendix S1. Comprehensive description of the nine indices used to compute the four conservation objectives.

Table S1. List of species, origin, conservation status, fishing interest, predicted occurrence frequency and AUC. 